\title{
Extra-Periosteal Plate Fixation of Ankle Fractures
}

\author{
HOSSAM A. ELSOUDANY, M.Sc.; ELSAYED M. ELFORS, M.D.; WALID MOHAMED EWIS, M.D. and \\ EMAD ABDEL-FATTAH ELMEHY, M.D.
}

The Department of Orthopedic, Faculty of Medicine, Tanta University

\begin{abstract}
Background: Open reduction and internal fixation with plate and screws is the standard operative treatment for displaced or unstable malleolar fractures, as it allows for a stable mechanical environment for healing. However, extensive surgical dissection can lead to devitalization of the fracture fragments and their soft tissue attachments, resulting in delayed union, non-union, and infection. Hence, a balance is necessary between anatomic reduction and soft tissue devitalization.

Aim of Study: Was to evaluate the results of extra-periosteal plate fixation in ankle fractures.

Patients and Methods: This study was done on 21 patients with closed ankle fractures who were admitted to Department of Orthopaedics, Tanta University Hospitals. The distribution of patients was according to age, sex, side, mode of trauma, lauge hansen classification type of fracture, medical history, smoking, time lag and associated injuries. Fixation was done by extra-periosteal plating technique. Clinical evaluation was according to Baird and Jackson scoring system.
\end{abstract}

Results: There were significant statistical correlation between the time of union and mode of trauma, associated injuries, associated medical condition and Time lag.

Conclusion: Extra-periosteal plating of ankle fractures is an effective method of stabilization that leads to predictable union of the fibular fracture. The results of this procedure are at least as good as those of other techniques of open reduction and internal fixation of the ankle.

Key Words: Devitalization - Extra-periostealplating technique - Malleolarfractures.

\section{Introduction}

ANKLE fractures are common musculoskeletal injuries that occur in a bimodal distribution with peaks in younger men and older women, the former related to high-energy trauma and the latter to osteopenia and osteoporosis. Although ankle fractures currently account for $9 \%$ of fractures, inci-

Correspondence to: Dr. Hossam A. Elsoudany, The Department of Orthopedic, Faculty of Medicine, Tanta University dence and severity are increasing, this is attributed to the increased life expectancy among older individuals and improved survival of patients with severe foot and ankle trauma [1,2].

An asymmetry of the articulation between the talus, the tibia and the fibula suggest ankle instability. A cadaveric study by Ramsey and Hamilton [3] founded that $1 \mathrm{~mm}$ of tibiotalar displacement may decrease ankle joint contact area by $42 \%$, hence the goal of surgical fixation of ankle fractures is to restore the integrity of the joint and near physiologic biomechanics [4]. It is now universally agreed that perfect reduction with rigid fixation is the cornerstone in preventing or at least delaying the onset of arthritic changes of the ankle joint after such serious injury [ $\boldsymbol{r}$

Open reduction and internal fixation with plate and screws is the standard operative treatment for displaced or unstable malleolar fractures, as it allows for a stable mechanical environment for healing. However, extensive surgical dissection can lead to devitalization of the fracture fragments and their soft tissue attachments, resulting in delayed union, non-union, and infection. Hence, a balance is necessary between anatomic reduction and soft tissue devitalization [6,7].

In an effort to help reducing the surgical morbidities, the use of an extraperiosteal approach, which minimally disrupts the blood supply, allows for less periosteal stripping, and maintains the softtissue attachments to the fracture fragments, which aids in obtaining the reduction, increases callus formation, and provides optimal healing environment $[8,9]$

\section{Patients and Methods}

This study is prospective study included 21 patients with closed ankle fractures who were 
admitted to Department of Orthopaedics, Tanta University Hospitals between August 2017 and August 2018 treated by extra-periosteal plate fixation. Patients were followed-up clinically and radiologically, and the period of follow-up ranged from 6 to 12 months.

A written informed consent was obtained from every patient, in case of any unexpected risks appearing during the course of the research. This will be cleared to the participants and to the ethical committee in time. Privacy of participants and confidentiality of the data will be given the most care and attention. Each patient data file, including investigations will be code-assigned and only the code will be used in data management without disclosure of patient's name or personal information.

\section{Inclusion criteria:}

Included patients age from 20-60 years, closed injuries, isolated lateral malleolus fractures and Bimalleolar.

\section{Exclusion criteria:}

Patients age under 20 or over 60 years, patients with open fractures, patients with uncontrolled diabetes mellitus and pre-existing arthrosis of the ankle.

All the patients were subjected to the following: Full history taking including mode and time of trauma clinical examination: General examination, musculoskeletal examination, local examination: Including neurovascular examination and soft tissue condition assessment.

\section{Investigations:}

\section{1- Laboratory investigations: Full lab.}

2- Radiological investigations: Plain X-ray (Anteroposterior, lateral and mortise views) of the ankle joint. In case of ligamentous injuries, stress films may be utilized.

Surgical technique: Under complete aseptic technique, the incision is centered over the posterior one half of the fibula. When the incision has been made through the skin, care is taken not to incise the periosteum. It is found immediately subcutaneously and often has small rents in it as part of the injury, which can make it difficult to recognize. The periosteum is left entirely intact individual fracture fragments are not identified, stripped, or further handled.

Once the dissection is at the level of the periosteum, all retractors are removed from the wound as they can shorten the fibula because of the tension placed on the surrounding soft tissues.

Reduction is obtained by manipulating the foot, reduction of fracture site by reduction clamp and maintain it by $\mathrm{K}$ wire. Multiple options exist for maintaining the reduction including: Independent lag screws or lag screws through the plate then fixation by a straight one-third tubular plate that is contoured to the shape of the distal aspect of the fibula is placed above the periosteum. It is vital that the plate be slightly undercontoured in relation to the lateral surface of the fibula as this ultimately corrects the lateral translation of the fibula. The plate is placed onto the fibula, ensuring that it is centered between the anterior and posterior borders of the bone. Once appropriate plate position is confirmed screws can then be placed, from proximal to distal, which will push the fibula (and therefore the talus) medially. If the ankle fracture is bimalleolar, the first step is to open the medial fracture site, to reduce the fragments, and then to stabilize the fracture with lag screws or tension band then closure of subcutaneous tissue and skin with interrupted sutures.

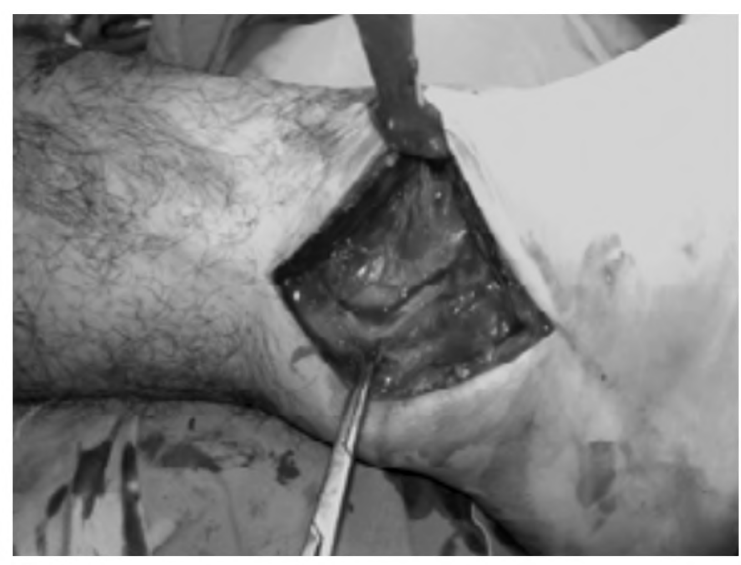

Fig. (1): Intact periosteum.

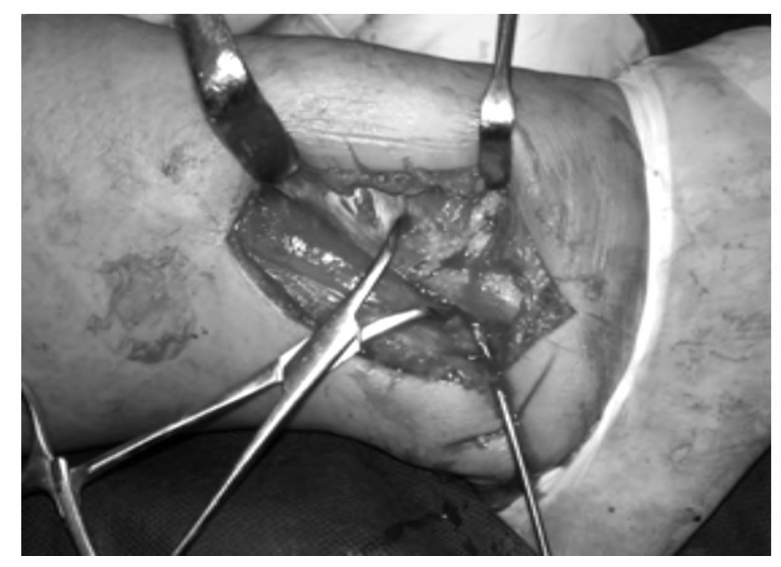

Fig. (2): Reduction of the fracture site using reduction clamp and maintaining the reduction by $\mathrm{k}$-wire. 




Fig. (3): Fixation by plate and screws.

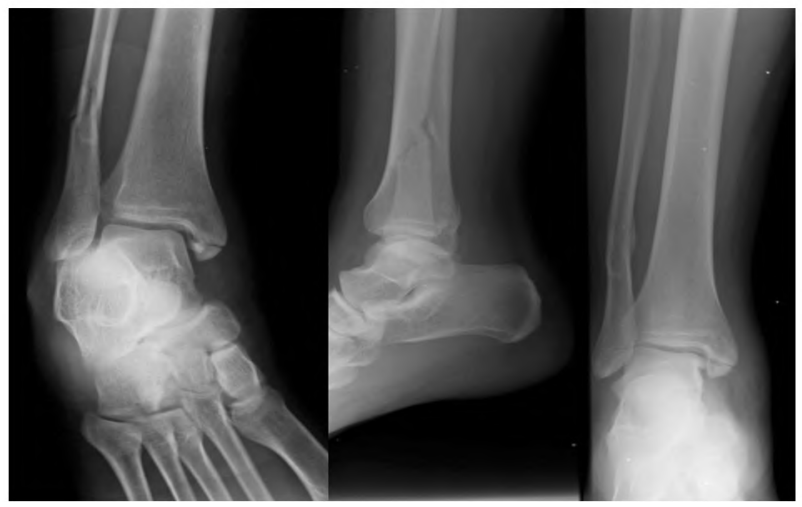

Fig. (4): Pre-operative X-rays for AP, lateral and mortise radiographs pronation abduction case.

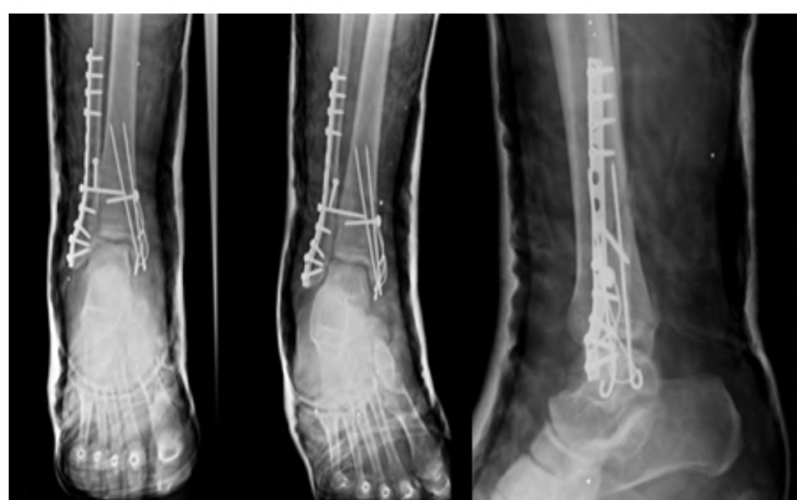

Fig. (5): Post-operative X-rays for AP, lateral and mortise radiographs pronation abduction case.

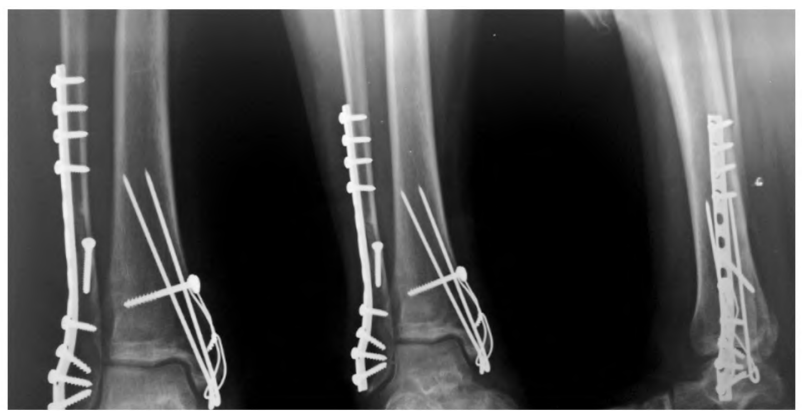

Fig. (6): Follow-up X-rays AP, lateral and mortise radiographs after 3 months.
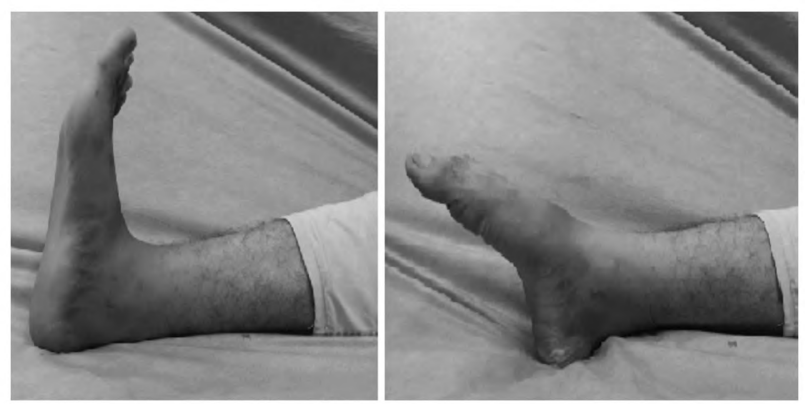

Fig. (7): Clinical outcome, patient achieves normal range of motion during dorsiflextion and planter flexion.

Statistical presentation and analysis of present study was conducted using the mean value and chi-square test by SPSS V. 16. $p$-value $\leq 0.05$ significant, $p$-value $>0.05$ not significant, $p$-value $<0.01$ highly significant.

\section{Results}

The results were assessed according to the Baired and Jackson scoring system for ankle fractures. Four patients $(19 \%)$ had excellent results, thirteen patients $(62 \%)$ had good results. Two patients $(9.5 \%)$ had fair results and two patients $(9.5 \%)$ had poor results. The excellent and good results were considered as satisfactory and the unsatisfactory ones included the fair and the poor results. Thus, satisfactory results were found in 17 patients $(81 \%)$, and the unsatisfactory ones were found in 4 patients (19\%).

Table (1): Grades of final functional clinical score.

\begin{tabular}{|c|c|c|c|c|c|c|c|c|c|c|c|c|c|}
\hline \multicolumn{6}{|c|}{ Satisfactory } & \multicolumn{6}{|c|}{ Unsatisfactory } & & \\
\hline \multicolumn{2}{|c|}{ Excellent } & \multicolumn{2}{|c|}{ Good } & \multicolumn{2}{|c|}{$\begin{array}{c}\text { Total } \\
\text { Satisfactory }\end{array}$} & \multicolumn{2}{|c|}{ Fair } & \multicolumn{2}{|c|}{ Poor } & \multicolumn{2}{|c|}{$\begin{array}{c}\text { Total } \\
\text { Unsatisfactory }\end{array}$} & \multicolumn{2}{|c|}{ Total } \\
\hline $\mathrm{N}$ & $\%$ & $\mathrm{~N}$ & $\%$ & $\mathrm{~N}$ & $\%$ & $\mathrm{~N}$ & $\%$ & $\mathrm{~N}$ & $\%$ & $\mathrm{~N}$ & $\%$ & $\mathrm{~N}$ & $\%$ \\
\hline 4 & 19 & 13 & 62 & 17 & 81 & 2 & 95 & 2 & 95 & 4 & 19 & 21 & 100 \\
\hline
\end{tabular}


Table (2): Shows factors affecting the final clinical result and the time of union, $p$-value for each factor and if it is significant or not.

\begin{tabular}{|c|c|c|c|c|c|c|c|c|}
\hline & \multicolumn{4}{|c|}{ Final clinical result } & \multicolumn{2}{|c|}{ Time of union } & \multirow{2}{*}{$\begin{array}{l}p \text {-value for } \\
\text { clinical result }\end{array}$} & \multirow{2}{*}{$\begin{array}{l}p \text {-value for } \\
\text { time of union }\end{array}$} \\
\hline & Excellent & Good & Fair & Poor & 8 weeks & $>8$ weeks & & \\
\hline \multicolumn{9}{|l|}{ Age: } \\
\hline $20-<30$ & 1 & 3 & 0 & 0 & 4 & 0 & 0.3920 & 0.6899 \\
\hline $30-<40$ & 0 & 5 & 0 & 0 & 5 & 1 & & \\
\hline $40-<50$ & 2 & 2 & 1 & 2 & 5 & 2 & & \\
\hline$>50$ & 1 & 3 & 1 & 0 & 3 & 1 & & \\
\hline \multicolumn{9}{|l|}{ Sex: } \\
\hline Male & 1 & 6 & 0 & 1 & 4 & 13 & 0.5724 & 0.2916 \\
\hline Female & 3 & 7 & 2 & 1 & 2 & 2 & & \\
\hline \multicolumn{9}{|l|}{ Mode of trauma: } \\
\hline Twisting trauma & 4 & 8 & 1 & 1 & 10 & 4 & 0.0003 & 0.7815 \\
\hline FFH & 0 & 0 & 1 & 1 & 1 & 1 & & \\
\hline MVA & 0 & 5 & 0 & 0 & 3 & 2 & & \\
\hline \multicolumn{9}{|l|}{ Medical history: } \\
\hline Present & 0 & 1 & 1 & 2 & 1 & 3 & 0.0082 & 0.0015 \\
\hline Absent & 4 & 12 & 1 & 0 & 16 & 1 & & \\
\hline \multicolumn{9}{|l|}{ Smoking: } \\
\hline Smoker & 0 & 5 & 0 & 0 & 3 & 2 & 0.2573 & 0.1716 \\
\hline Non-smoker & 4 & 8 & 2 & 2 & 14 & 2 & & \\
\hline \multicolumn{9}{|l|}{ Type of fracture: } \\
\hline SER & 4 & 9 & 1 & 1 & 12 & 3 & 0.8878 & 0.3234 \\
\hline PER & 0 & 2 & 1 & 1 & 2 & 2 & & \\
\hline PA & 0 & 2 & 0 & 0 & 2 & 0 & & \\
\hline \multicolumn{9}{|l|}{ Time lag: } \\
\hline $1^{\text {st }}$ week & 4 & 11 & 1 & 0 & 16 & 2 & 0.0304 & 0.0360 \\
\hline 2nd week & 0 & 2 & 1 & 2 & 1 & 2 & & \\
\hline \multicolumn{9}{|l|}{ Time of union: } \\
\hline 8 weeks & 4 & 12 & 1 & 0 & & & 0.0082 & \\
\hline$>8$ weeks & 0 & 1 & 1 & 2 & & & & \\
\hline
\end{tabular}

\section{Discussion}

In the current study the satisfactory results were obtained in 17 cases ( 4 excellent and 13 good) representing $(81 \%)$. Unsatisfactory results were 2 fair cases representing $(9.5 \%)$ and 2 poor cases representing $(9.5 \%)$. These results were compared with that of Parvataneni et al., [10], Burnwell \& Charnley [5], Colton [11], De souza et al., [12] and Rajiv et al., [13].

In parvataneni series of 30 patients, $(86.6 \%)$ had good to excellent results, $(6.6 \%)$ had fair results and poor results in $(6.6 \%)$. Burnwell \& Charnley in their series of 132 patients $102(77 \%)$ had good to excellent results, $(17 \%)$ had fair results and $(6 \%)$ with poor results. In colton series of 26 patients, $(70 \%)$ had good to excellent results, $(15 \%)$ had fair results and $(15 \%)$ with poor results. De souza series of 150 patients treated by open reduction and internal fixation using AO/ASIF method, obtained (90\%) good to excellent results, $(6 \%)$ had fair results and (4\%) had poor results. In Rajiv series of 53 patients, good to excellent results obtained in (83\%) of cases, $(13.3 \%)$ had fair and $(3.7 \%)$ of the cases had poor results.

In this study, fractures were common in the 4050 years age group, with the mean age being 39.8 years. This conforms with the mean age reported by Girish N. et al., [14] with mean age of 39.2 years, Rajiv et al., [13] and Parvataneni et al., [10] with mean age of 37.7 years. The mean age of patients reported in other published series is higher reaching up to 56.45 years in the series of Santosh S. et al., [15], Bauer et al., [16], Van Laarhoven C. et al., [17]. In this study the age was not a significant factor in determining the final clinical results. The same reported by Lindsjo U. [18] and Girish N. et al., [14]

In this study, males presented by eight cases while, female patients were 13 cases, with male to female ratio (1:1.63), showing female predominance. This conforms with other workers reported a female predominance such as Gauthe R. et al., [19] in a retrospective study included 477 patients 81\% were female and Beris AE et al., [20] where 
$88 \%$ of fractures were in women with male to female ratio (1:1.57), this could be due to underlying osteopenia or osteoporosis in the female population with ages more than 45 years. This was in contrast to the study of Miroslav Kilian et al., [21] reported male predominance $(54.2 \%)$, with male to female ratio (1.2:1), Rajiv et al., [13] $(62.3 \%)$ were males, with male to female ratio $(1.65: 1)$ and Santosh S. et al., [15] male to female ratio $(1.4: 1)$.

In this study, the right side (57\%) was affected more than left side $(43 \%)$ in ratio of (1.3:1) that conforms with Rajiv et al., [13] accounted for (70\%), Girish N. et al., [14] reported (62.5\%) right side affection, Beris AE et al., [20] reported (51\%) and (62\%) in Amlan et al., [22]. This is in contrast to the studies of Guru Prasad et al., [23], Santosh S. et al., [15] and Dhoom [24] where left side more affected.

In this study there was a relatively low number of smokers account for (24\%), that was statistically insignificant conforms with Egol KA et al., [25] however, Gauthe R. et al., [19] reported to be significant and Nåsell $\mathrm{H}$ et al., [26] in a dedicated study comparing the outcome between smokers and non-smokers in 906 patients with operatively treated ankle fractures, concluded that smoking was associated with more post-operative complications and worse functional outcome.

In this study, the type of fracture and mechanism of injury was obtained from the radiological finding as most of the patients in our study were unable to give reliable information about the direction of forces at time of injury. Lauge-Hansen classification system was used for operative evaluation. The most common type of fracture was supinationexternal rotation about $(71 \%)$ conforms with Parvataneni et al., [10] account for (46.6\%), Santosh S. et al., [15] account for (60\%), Rajiv et al., [13] reported (54.7\%) and Girish N. et al., [14] reported (40\%). Type of the fracture was found to have no significant effect in the results.

In this study, the time elapse before surgery was found to have statistically significant effect in the end results. The highest incidence of satisfactory results was found in patients managed with in the 1 st week while patients managed within 2 nd week had unsatisfactory results. This goes with the findings of Burnwell \& Charnley [5]

The overall infection rate in this series amounted to $(9.5 \%)$, two cases had superficial wound infection. Infection occurred within the first week after surgery that was resolved with appropriate IV antibiotic combination according to wound culture and sensitivity and with daily dressing. This rate is superior to the results of Vijay et al., [27] reported (16.67\%) and Dhoom [24] study had 4 patients with superficial infection (14.8\%) but inferior to the results of Parvataneni et al., [10] 2 cases with infection (6.6\%), Guru Prasad et al., [23] 7 cases had infection (7.3\%) and Van Laarhoven C. et al., [17] reported 6 cases $(7.4 \%)$.

In this study, delayed union was found in one cases $(4.7 \%)$, compared with (3\%) in the study of Guru Prasad et al., [23] and one case (1.2\%) in the study of Van Laarhoven C. et al., [17]. In contrast Dhoom [24] study reported no cases with delayed union.

In this study, Sudeck's atrophy was to be found in one case (4.8\%) compared to the study of Van Laarhoven C. et al., [17] reported in 2 cases $(2.5 \%)$ that might be due to prolonged cast duration.

In this study, 15 patients (71\%) achieved near normal range of motion in the operated side with less than 10 degrees difference compared to the non-operated side, while 6 patients $(29 \%)$ had 10 15 degrees loss of range of motion compared to normal side. The range of motion was decreased in Rajiv et al., [13] due to stiffness secondary to immbolization for 4 weeks but improved initially after removal of cast and the same also in Girish N. et al., [14].

In this study, the average time of union was $10-14$ weeks in $80 \%$ of patients compared to the study of Krishna et al., [28] in 30 patients union occurred in $66.6 \%$ of patients within 10-14 weeks and Girish N. et al., [14] average time taken for union was 10.4 weeks.

\section{Conclusion:}

- Extra-periosteal plating of ankle fractures is an effective method of stabilization that leads to predictable union of the fibular fracture. The results of this procedure are at least as good as those of other techniques of open reduction and internal fixation of the ankle, although specific results for extraperiosteal plating of ankle fractures have not been reported to our knowledge well.

- The earlier interference especially in non-smoker patients with no comorbidities, the better results obtained.

\section{Acknowledgements:}

This research was carried out without funding. 


\section{Conflicts of interest:}

No conflicts of interest declared.

\section{Authors contributions:}

All authors had equal role in design, work, statistical analysis and manuscript writing. All authors have approved the final article work.

\section{References}

1- COURT-BROWN C.M., McBIRNIE J. and WILSON G.: Adult ankle fractures an increasing problem? Acta Orthopaedica Scandinavica, Jan. 1, 69 (1): 43-7, 1998.

2- TARTAGLIONE J.P., ROSENBAUM A.J., ABOUSAYED M. and DiPRETA J.A.: Classifications in brief: LaugeHansen classification of ankle fractures. Clin. Orthop. Relat. Res., 473 (10): 3323-8, 2015.

3- RAMSEY P.L. and HAMILTON W.I.: Changes in tibiotalar area of contact caused by lateral talar shift. JBJS. Apr. 1, 58 (3): 356-7, 1976.

4- WOODWARD C. and DONEGAN D.: Operative technique: A modification of the "push-pull screw" distraction technique for obtaining fibular length. UPOJ, 25: 18. 20, 2015.

5- BURWELL H.N. and CHARNLEY A.D.: The treatment of displaced fractures at the ankle by rigid internal fixation and early joint movement. The Journal of bone and joint surgery. British volume. Nov., 47 (4): 634-60, 1965.

6- PIRES R.E., MAUFFREY C., De ANDRADE M.A., FIGUEIREDO L.B., GIORDANO V., BELLOTI J.C. and DOS REIS F.B.: Minimally invasive percutaneous plate osteosynthesis for ankle fractures: A prospective observational cohort study. European Journal of Orthopaedic Surgery \& Traumatology, Oct. 1, 24 (7): 1297-303, 2014.

7- SAXENA A. and YUN A.: Percutaneous Plating of Weber B Fibular Fractures. J. Foot Ankle Surg., 56 (2): 366-70, 2017.

8- SIEGEL J. and TORNETTA P.: Extraperiosteal plating of pronation-abduction ankle fractures. Surgical technique. J. Bone Joint Surg. Am., 90 Suppl 2 (Part 1): 135-44, 2008.

9- McMILLEN R.L. and GRUEN G.S.: Advancements in Percutaneous Fixation for Foot and Ankle Trauma. Clin. Podiatr. Med. Surg., 28 (4): 711-26, 2011

10- PRATHAP P., HS A. and KONDLAPUDI A.: Functional outcome in surgical management of Bi-malleolar fractures in adults, 2 (4): 72-6, 2016.

11- COLTON C.L.: The treatment of Dupuytren's fracture dislocation of the ankle. J. Bone Jt. Surg., 53: 63-71, 1971.

12- De SOUZA L.J. and GUSTILO R.B. M.T.: Results of operative treatment of displaced external rotationabduction fractures of ankle. J. Bone Jt. Surg., 67A: 10667,1985 .

13- RAJIV MARIO COLACO, NAIK LOKESH GUDDA G., 3 WAYBASE ASHOK HANUMANT, 4 SHARMA GAURAV MAHESH, 5 QURESHI FAISAL and 6 KRISHNA BADGIRE: Functional outcome of surgical management of malleolar fractures of the ankle joint using BairdJackson scoring-A prospective study. Int. J. Med. Heal. Res., 3 (1): 42-5, 2017.

14-GIRISH N. MOTWANI1, HIMANSHU D. SHAH1, VISHWANATH H. CHAVLI1 R.N.D. and HARESH PARMAR1 P.P.S.: Results of open reduction and internal fixation in closed bimalleolar Pott's Fracture of Ankle in Adults, 4 (7): 893-900, 2015.

15- KULLOLI S.S., MAGDUM P.B. and NAIK N.P.: Evaluation of Management of Malleolar Fractures of Ankle Joint, 3 (3): 27-3 1, 2012.

16- BAUER M., BERGSTRÖM B., HAMBURG A. and SANDEGARD J.: Malleolar Fractures: Nonoperative versus Operative Treatment. Clin. Orthop., 199: 17-27, 1985.

17- DONKEN C.C.M.A., AL-KHATEEB H., VERHOFSTAD M.H.J. and VAN LAARHOVEN C.J.H.M.: Surgical versus conservative interventions for treating ankle fractures in adults. Cochrane database Syst. Rev., 8, 2012.

18- U.L. Operative treatment of ankle fracture-dislocations: A follow-up study of 306/321 consecutive cases. Clin. Orthop., 199: 28-38, 1985.

19- GAUTHÉ R., DESSEAUX A., RONY L., TARISSI N. and DUJARDIN F.: Ankle fractures in the elderly: Treatment and results in 477 patients. Orthop. Traumatol. Surg. Res., 1-4, 2016.

20- BERIS A.E., KABBANI K.T., XENAKIS T.A.M.G. and SOUCACOS P.K.S.P.: Surgical treatment of malleolar fractures-a review of 144 patients. Clin. Orthop. Related Research, p. 341: 90-8, 1997.

21- MIROSLAV KILIANA, PETER CSÖRGÖA, SILVIA VAJCZIKOVAA and JAN LUHAB R.Z.: Journal of Clinical Orthopaedics and Trauma Antiglide versus lateral plate fi xation for Danis-Weber type B malleolar fractures caused by supination-external rotation injury. J. Clin. Orthop. Trauma (March 2014).

22- MOHAPATRA A. and RAJ K.: Functional outcome after surgical treatment of ankle fracture using Baird Jackson score, 4 (4): 638-41, 2018.

23- SULTANPURKAR G.P., HARANADH K. and HARSHA K.: A retrospective study of functional outcome of surgically managed malleolar fracture at the ankle joint by subjective, objective and radiological assessment, 3 (4): 466-74, 2017.

24- JHATOTH D.S.: Evaluation and surgical management of bimalleolar fractures of ankle joint, 3 (3): 620-3, 2017.

25- EGOL K.A., DOLAN R. and KOVAL K.J.: Management In A Cast or A Functional Brace, 246-9, 2000.

26- NÅSELL H., OTTOSSON C., TÖRNQVIST H. and LINDÉ J.P.S.: The impact of smoking on complications after operatively treated ankle fractures-a follow-up study of 906 patients. J. Orthop. Trauma, 25 (12): 748, 2011.

27- VIJAY KARANDE, VIVEK P. NIKUMBHA A.D. and GKNG: Study of surgical management of malleolar fractures of ankle in adults, 3 (3): 783-7, 2017.

28- VEM K.B., KONDLAPUDI A.K., MURARI S.K. and D.S.M.: Outcome of Surgical Management of Bimalleolar Fractures In Adults, 10 (11), 2017. 


\section{تثبيت كسور الكاحل بواسطة شريحة خارج السمحاق}

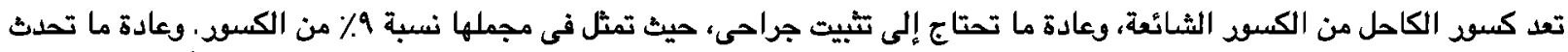


بالعظام.

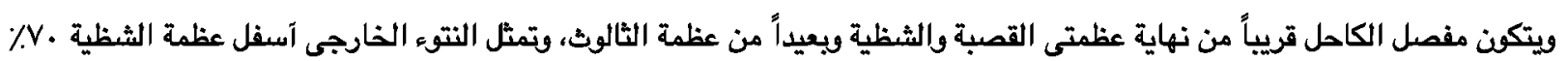

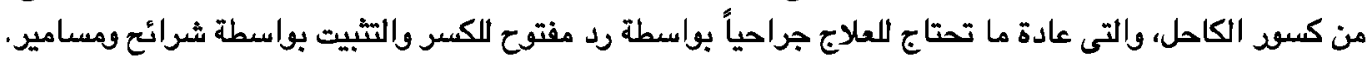

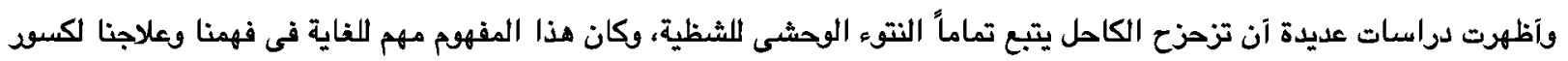

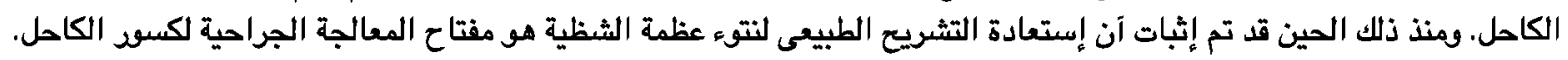

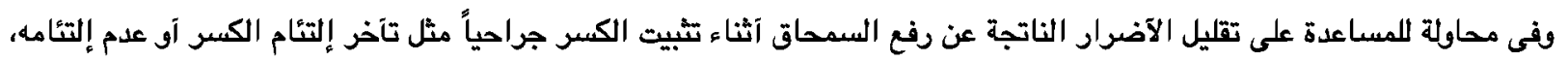

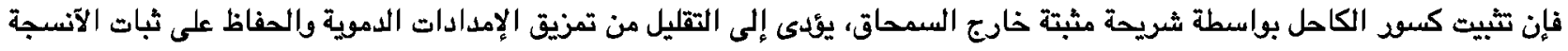
الرخوة للآجزاء المكسودة من العظمة، مما يساعد على إلتئام الكسر بطريقة ملائمة.

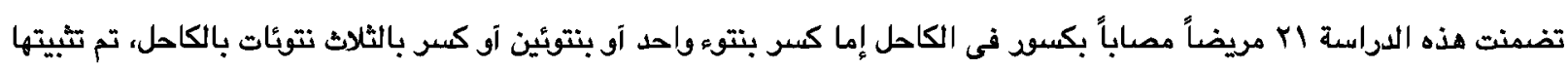


جراء إصابة إلتوائية بالكاحل آو نتيجة لحادث سير فير.

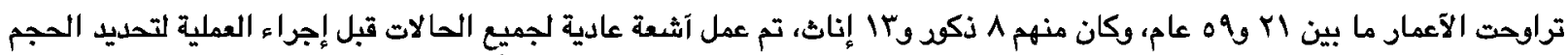

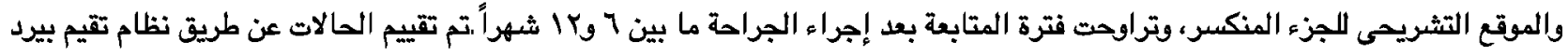

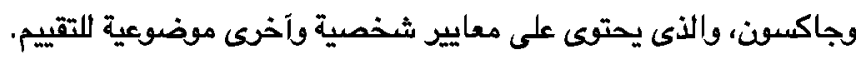

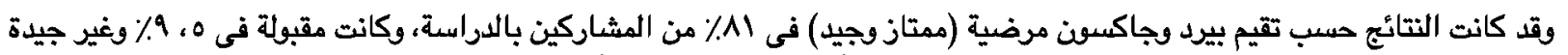

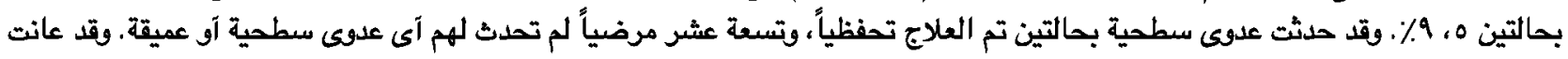

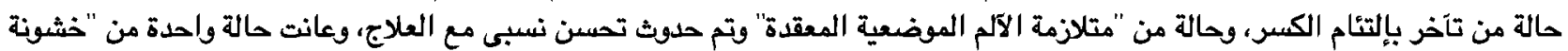
ما بعد الإصابة"،

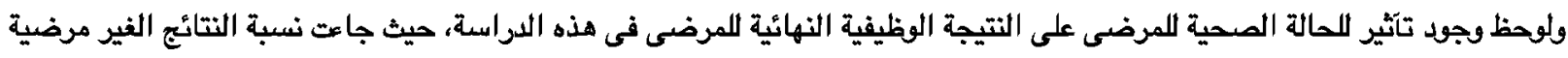

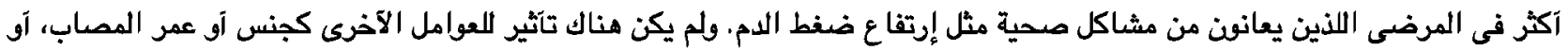
التخين ، آو طريقة حدوث الإصابة.

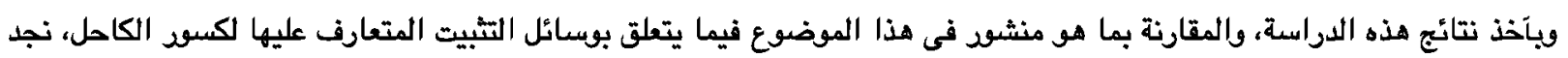

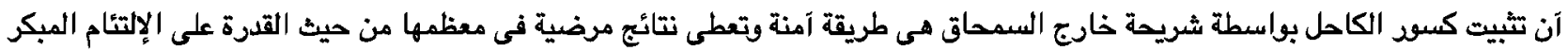

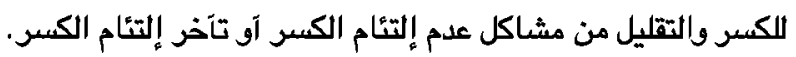

